\title{
The influence of the institutional environment on public-private partnership transport projects
}

\author{
J. Pérez-D’Oleo ${ }^{1}$, C. Castro ${ }^{1}$, I. Herraiz ${ }^{2} \&$ S. Carpintero ${ }^{1}$ \\ ${ }^{1}$ Polytechnic University of Madrid, School of Civil Engineering, Spain \\ ${ }^{2}$ Independent researcher, Spain
}

\begin{abstract}
Public-private partnerships (PPP) have become a key tool in the provision and management of transport infrastructure projects providing countries access to the necessary financial resources for infrastructural needs. Despite the increasing number of PPP projects implemented in many countries, there are factors that hinder development of these projects. One of these factors is the weakness of the institutional environment, particularly in developing countries. To date, few empirical studies have analysed the effects of public institutions on PPP projects, despite the relevance of this issue. The objective of this paper is to analyse the influence of institutional environment on the investment carried out through public-private partnerships in middle-and-low income countries for the period 1996-2011. This paper carries out a statistical analysis of the institutional environment indicators, and data of public-private investment, for 80 countries. Our analysis identifies the most relevant institutional factors that affect the implementation of PPP projects.
\end{abstract}

Keywords: transport infrastructure, governance, public-private partnerships, developing countries.

\section{Introduction and motivation}

Transport infrastructure is of vital importance for any country, with deep direct and indirect socioeconomic effects. Many developing countries face an increasing demand of infrastructure that these countries are not capable to supply because of lack of resources. Scarcity of public resources and a desire to optimise their use in the provision of infrastructure have led many countries 
to boost the use of public-private partnerships (PPP) over the last two decades [1]. As a result, 1170 transport projects in middle-and-low income countries have been financially closed in the period 1996-2011, with a total investment of USD 291.56 billion [2].

Nonetheless, PPP projects face numerous obstacles in their implementation causing that a lot of countries are not attractive for this kind of agreements. These obstacles derive from the complexity and long-term duration of the contracts, as well as from the need to obtain long-term financing backed only by the project cash flow. An underlying challenge, especially in developing countries, is the weakness of the institutional environment - the efficient, fair, independent and competent functioning of public institutions such as ministries, regulators, courts, etc. [1].

Institutions are key to create an investment climate where competence is feasible, prices are market driven and repayment period of the investments is short [3]. Several studies [4-7] point out that the implementation of PPP projects in a country depend on the existence of a high level of: 1) public and corporate governance; 2) transparency and law enforcement, which includes property law and contractual rights; 3) control of corruption and appropriate regulatory framework.

To date, few studies have analysed the effects of institutional environment in PPP projects, despite the relevance of this issue. An important reason is the difficulty to quantify this institutional environment to derive statistical analysis. The World Bank Governance Indicators Database (WGI) [8] provides confident intervals for particular set of indicators that are difficult to treat with standard statistical methods as regression models. The aim of this paper is to analyse these data to establish whether the institutional environment has a significant influence on the implementation of PPP transportation projects in middle-and-low income countries. The conclusions are based on an empirical analysis of data for 80 middle-and-low income countries around the world for the period 1996-2011. Data on PPP transportation projects is from the Private Participation in Infrastructure (PPI) Project Database [2].

The paper is organised as follows. Section 2 reviews the literature related with the case study. Section 3 provides a description of the variables selected to characterise the institutional environment and the implementation of PPP transportation projects as well as the methodology used for the statistical analysis. Section 4 presents the results of the empirical analysis. Finally, section 5 presents the conclusions and a summary of the issues considered.

\section{Related work}

In the last years there has been an increasing interest to identify and quantify the link between the institutional environment and PPP projects. Literature related to this topic frequently considers the institutional environment as one of many determining factors in the development of infrastructure PPP projects, and conclusions about the impact of institutions are mixed. Pargal [9] analyses the importance of the regulatory framework related to the private sector investment 
in infrastructure in nine Latin-American countries in the period 1980-1998. He shows that government actions to create independent regulatory bodies, which guarantee legal security and minimise expropriation risks, are positively related with private investment.

Jensen and Blanc-Brude $[10,11]$ have examined the relation between institutions and private participation in hydro-sanitary infrastructures in 60 developing countries. Data about the private investment in the sector were obtained from the Watsan PSP database and data about the institutions were taken from the WGI Database and the ICRG investment profile index. Authors claim that institutions which support and guarantee acquired commitments by the government with private partners are important for the implementation of projects with private sector involvement. Protection of investors against expropriation and quality of bureaucracy are significant factors to attract and capture private investment.

However, rule of law and control of corruption have a lower degree of significance; and political stability and contractual laws are not soundly significant. This study recommends to be careful with the interpretation of the results of governance indicators, because some of them present multicollinearity, probably because these indicators capture attributes similar to governance. Moreover, the paper also points out the need to identify and try more accurate measures of institutional environment aspects.

Another study related to hydro-sanitary infrastructures was performed by Al-hmoud and Edwards [12]. The analysis aims to identify the economic, political and demographic factors that determine the appropriate environment for the private sector participation in 39 developing countries, during the period 1996-2001. The six governance indicators of the WGI database were used to represent political factors. The authors claim that political and demographic variables do not have a significant impact on the likelihood to achieve a financial closing with the private sector, whereas economic variables do. This result could be interpreted in a way that a stable economy is sufficient to offset weaknesses in the political system of a country. But Al-hmoud and Edwards [12] claim that the result of the political variables in the analysis may be conditioned by the methodology used to collect the data or because of the treatment of variable in the empirical analysis.

Percoco [13] shows empirically that quality of institutions is one of the determining factors for the private sector to assume bigger risk in transportation PPP projects. The study uses a measure of risks allocation based in four types of contracts signed, as well as the Worldwide Governance Indicators of developing countries. The results show that political and civil rights and an appropriate business environment in terms of rule of law and regulatory framework are important for the participation of private investors in PPP agreements. Moreover, this study claims that there is a negative relation between corruption and private investment in infrastructure.

Chan et al. [14] identifies the critical factors to carry out PPP projects for the development of infrastructure in China. The results are based on a survey carried out with the involvement of experts and analyse 18 critical factors previously 
identified. The authors claim that an independent and transparent legal framework allows the creation of profitable contracts and agreements, and contributes to the stability of such agreements. Furthermore, the results show that transparency in the engagement process reduces transactional costs and negotiation time.

Another research with a similar approach was carried out by Zhang [15]. This author claims that for the development of PPP projects it is needed to have adequate political, legal, economical and trade environments. Environments with stable political systems, predictable and reasonable legal frameworks, and governmental support allow the management and reduction of risks to which the private sector are exposed. Such risks include expropriation, legal change, corruption, and transparency in evaluation processes, among others.

Hammami et al. [16] aligns with previous studies in saying that control of corruption and rule of law contribute positively to attract private capital to infrastructure projects. In relation to transportation sector, Hammami et al. [16] shows that PPP projects are more frequent in environments with a legal environment, specifically rule of law, which protect the right of investors. Sharma [17] provides some evidence to support that political stability and regulatory quality are determining factors for the participation of private companies in PPP projects in developing countries. However, it also claims that countries with efficient public sectors tend to keep construction and maintenance of infrastructure in the sector, and private investment is lower. Such results are based in the study of 22 developing countries during the period 1990-2008.

\section{Methodology}

\subsection{Data retrieval}

Our analysis is based on three different sources of data, World Bank's Private Participation in Infrastructure Projects Database (PPI), the World Bank's Governance indicators (WGI), and the World Bank's World Development indicators $[2,8,18]$.

The variables representing the institutional environment have been taken from the WGI Database. This database registers information about six indicators for 215 countries for the period 1996-2013. Governance aggregated indicators compile information of 32 individual data sources which report the perceptions and experiences of citizens, businessmen, private and public sectors experts, as well as those of nongovernmental organisations about different governance aspects. The individual sources are combined to generate the governance indicators using the non-observed components model [19].

WGI Database is based on qualitative data because citizens and companies act depending on perceptions and points of view in regards to governance performance. Additionally, there are governance aspects, which are difficult to measure because they do not leave any straightforward trail, as can be the case with corruption. Another advantage of using subjective information is that, in 
certain cases, objective information about governance aspects is based on official definitions which differ from reality [20].

Kaufmann et al. [19] defines governance as the traditions and institutions by which authority in a country is exercised. This includes: 1) the process by which governments are selected, monitored and replaced; 2) the capacity of the government to effectively formulate and implement sound policies; and 3 ) the respect of citizens and the state for the institutions that govern economic and social interactions among them.

The six aggregated indicators, which try to capture this definition, are:

Voice and Accountability (VA) - capturing perceptions of the extent to which a country's citizens are able to participate in selecting their government, as well as freedom of expression, freedom of association, and a free media.

Political Stability and Absence of Violence $(P V)$ - capturing perceptions of the likelihood that the government will be destabilised or overthrown by unconstitutional or violent means, including politically-motivated violence and terrorism.

Government Effectiveness (GE) - capturing perceptions of the quality of public services, the quality of the civil service and the degree of its independence from political pressures, the quality of policy formulation and implementation, and the credibility of the government's commitment to such policies.

Regulatory Quality $(R Q)$ - capturing perceptions of the ability of the government to formulate and implement sound policies and regulations that permit and promote private sector development.

Rule of Law $(R L)$ - capturing perceptions of the extent to which agents have confidence in and abide by the rules of society, and in particular the quality of contract enforcement, property rights, the police, and the courts, as well as the likelihood of crime and violence.

Control of Corruption (CC) - capturing perceptions of the extent to which public power is exercised for private gain, including both petty and grand forms of corruption, as well as "capture" of the state by elites and private interests.

Data on PPP transportation projects describe investment in PPP projects in transportation infrastructure such as roads, railways, ports and airports. These data have been taken from the World Bank's Private Participation in Infrastructure Projects Database (PPI). This database currently provides information on more than 6,000 infrastructure projects dating from 1984 to 2013.

For this database, an infrastructure project is considered to have private sector participation if a private company participates with at least $25 \%$ of the contract of the project. The exception is for privatisations, for which the participation has to be higher than $5 \%$. In addition, the projects must have reached financial closure before the end of 2011. Data on investments in these projects capture investment commitments of the entity in charge of the project at the contract signing or financial closure. Total investment includes both investment in physical assets and payments to be made to the government (right to provide services, acquisition of public companies, etc.). Data are provided in USD million, and the investments are dated either the year in which they were formally announced or the year in which they were made. Data about population, 
Gross Domestic Product (GDP) and Gross Domestic Product per capita (GDP per capita) were obtained from the World Bank's World Development indicators.

\subsection{Statistical analysis}

\subsubsection{Data treatment}

The six governance indicators have values ranging from approximately -2.5 to 2.5 (the higher the value, the better the governance). For each estimated value, the database also provides an associated error, which provides confident intervals for each indicator, with $90 \%$ confidence.

Governance indicators are widely recognised and used in academic research, in developing economies and in debates. However, these indicators have also generate criticism, mainly about their methodological aspects, their use and interpretation [21-24]. For this reason, the following considerations have been taken into account for the empirical analysis:

First, Kaufmann et al. [25] claims that, due to the non-observable nature of governance in a country, any empirical estimate is going to be an imperfect approximation to the dimensions which are intended to be measured, which includes WGI data. Hence, governance estimates are subject to nontrivial margins of error which has to be taken into account in its interpretation. For this reason, rather than considering the estimates of the governance indicators as statistical variables, the analysis is based on confident intervals that take into account the standard error. The governance indicator are then interpreted in terms of these intervals assuming that values outside them cam be discarded with the given confidence.

Second, Kaufmann et al. [25] claims a useful and conservative rule of thumb is that when the margins of error overlap for two countries, or for two points in time, then the estimated differences in governance are too small to be statistically significant. Therefore, the proposed methodology is based on a clustering of different countries in three groups according to the governance indicator. The first group contains those countries for which we can discard a value greater than the average, the second one contains those for which we can discard a value lower than the average, while the third one is constituted by those countries for which the average value indicator is in their confidence interval. In this way, any two countries in groups one and two respectively have non-overlapping confident interval.

Third, the authors make other important observation governance indicators are not independent among them and are highly correlated. Thus, the analysis is performed independently for each governance indicator.

Fourth, Kaufmann et al. [25] shows that estimates of the six governance indicators register changes relatively small in most countries over time, based on the analysis of indications during the period 2000-2009. Furthermore, it shows that correlation between estimates increases when shorter periods are being considered. Hence, the analysis is performed for three periods, 1996-2001, 2002-2006 and 2007-2011. In the first period, there has been $24 \%$ of the total committed investment, the second one registered $26 \%$ of the investment and the third one accounted for $51 \%$. The different hypotheses are tested for the total 
committed investment registered in each period. These periods intend to reflect the evolution of the private investment in PPP projects during the period analysed, and also allow us to identify the effect in private participation caused by changes in governance in a country.

\subsubsection{Methodology}

The literature related suggests that institutional environment influences private participation in infrastructure projects. Based on this starting point, two hypotheses are presented in the analysis for each indicator:

$\mathrm{H}_{1}$ : Countries with high governance levels tend to have higher investment levels in transportation PPP projects.

$\mathrm{H}_{2}$ : Changes in a country's governance impact the level of investment in transportation PPP projects in such country.

The empirical analysis has been divided in three stages. First, one co-factor that allows us to normalise the variable of PPP investment projects for the different countries in the sample is identified. To do this, population, GDP and GDP per capita are evaluated as possible co-factors.

Second, countries are classified in three groups, according to the estimation of governance for each aggregated indicator in the years 1996, 2002 and 2007. Such estimation of governance captures all the potential values which a country can have according to its estimation and standard error associated to a $90 \%$ confidence level. This way, group 1 contains the countries with below average governance confidence interval, group 2 contains countries with above average confidence interval, and group 0 corresponds to countries with confidence intervals overlapped with groups 1 and 2 , and therefore no significant differences can be established between this group and the others.

Third, statistical hypothesis tests are performed to compare average investment in PPP projects in each period and in each governance indicator. To evaluate $\mathrm{H}_{1}$ in the hypothesis test, the following null hypothesis $\left(\mathrm{H}_{0}\right)$ is established:

$\mathrm{H}_{\mathrm{o}}$ : the average investment in groups 0,1 and 2 is the same as the average investment in the entire sample for the relevant period.

To test $\mathrm{H}_{2}$, the hypothesis tests compare the average investment in PPP in a group in two different periods in countries, which have registered group changes.

For this purpose, group A includes countries that have experienced a decline in the confidence of a specific governance indicator in the following sense: either they have entered in group A in the last period, i.e. the governance indicator can no longer be considered on the average or above, or they have disappeared form group B, i.e. the indicator that was clearly greater than the average in the previous period could be now lower than the average. Similarly, group B includes countries that recorded an improvement in the confidence of the governance indicator from one period to another. To carry out comparisons across periods 1996-2001 and 2007-2011 total investment of the sample is introduced as a co-factor of investment. This way, we try to avoid that some 
factors not included in the analysis such as financial market shocks impact on the results. In this case, null hypothesis is:

$\mathrm{H}_{\mathrm{o}}$ : average investment of a group is constant over periods.

\section{Results}

\subsection{Co-factor results}

Table 1 present the results of the Spearman's correlation analysis show that GDP registers a higher correlation index with investment, and such tendency is consistent across the three periods $(0.632,0.583$, and 0.462$)$. Population and GDP per capita present low correlation with investment. For this reason, from now anticipates GDP is considered as a co-factor for investment in PPP projects.

Table 1: $\quad$ Correlation matrix.

\begin{tabular}{|c|c|c|c|c|c|c|c|c|c|c|c|c|}
\hline & it9601 & pob96 & gdp96 & gdpc96 & it0206 & pob02 & gdp02 & gdpc02 & it0711 & pob07 & gdp07 & gdpc07 \\
\hline it9601 & 1.000 & & & & & & & & & & & \\
\hline pob96 & 0.455 & 1.000 & & & & & & & & & & \\
\hline gdp96 & 0.632 & 0.793 & 1.000 & & & & & & & & & \\
\hline gdpc96 & 0.435 & -0.044 & 0.517 & 1.000 & & & & & & & & \\
\hline it0206 & & & & & 1.000 & & & & & & & \\
\hline pob02 & & & & & 0.416 & 1.000 & & & & & & \\
\hline gdp02 & & & & & 0.583 & 0.793 & 1.000 & & & & & \\
\hline gdpc02 & & & & & 0.387 & -0.090 & 0.486 & 1.000 & & & & \\
\hline it0711 & & & & & & & & & 1.000 & & & \\
\hline pob07 & & & & & & & & & 0.388 & 1.000 & & \\
\hline gdp07 & & & & & & & & & 0.462 & 0.795 & 1.000 & \\
\hline gdpc07 & & & & & & & & & 0.251 & -0.011 & 0.545 & 1.000 \\
\hline
\end{tabular}

Notes: it (total investment committed), pob (population), gdp (Gross Domestic Product), gdpc (Gross Domestic Product per capita).

\subsection{Statistical hypothesis testing results}

Table 2 presents the results of the hypothesis testing of investment on PPP projects for each indicator and period, the significant results are indicated by an asterisk. In order to avoid scale issues, investment values by GDP are represented as natural logarithm.

The results for group 2 suggest that countries with high values of voice and accountability indicator tend to have higher investment in PPP projects in the periods 1996-2001 and 2002-2006, but in the period 2007-2011 the results are not statistically significant. In the period 2002-2006 high value of the indicators government effectiveness and regulatory quality reflect a positive influence on investment. Control of corruption shows significant results for the period 19962001. In group 1 the variables of political stability and absence, regulatory quality, and control of corruption reflect significant values, relate lower 
indicators values with lower investment, but they are significant only for one period.

The results for the indicators are not consistent over the three periods. Variables rule of law, and political stability and absence of violence do not allow establishing significant differences. Moreover, the results show that the number of countries with overlapping intervals (group 0) is higher during early periods.

Table 2: $\quad$ PPP Investment per period.

\begin{tabular}{|c|c|c|c|c|c|c|c|c|c|}
\hline \multicolumn{2}{|c|}{ WGI Indicators } & \multicolumn{8}{|c|}{ Investment PPPs } \\
\hline \multirow{2}{*}{ Period } & \multirow{2}{*}{ Group } & Obs. & $\mathrm{H}_{\mathrm{a}}: \mu<\mathrm{H}_{\mathrm{o}}$ & На: $\mu !=H_{o}$ & Ha: $\mu>\mathrm{H}_{0}$ & Obs. & $\mathrm{H}_{\mathrm{a}}: \mu<\mathrm{H}_{\mathrm{o}}$ & $\mathrm{Ha}: \mu !=\mathrm{H}_{0}$ & $\mathrm{Ha}: \mu>\mathrm{H}_{\mathrm{o}}$ \\
\hline & & \multicolumn{4}{|c|}{ Voice and Accountability (VA) } & \multicolumn{4}{|c|}{ Regulatory Quality (RQ) } \\
\hline \multirow{2}{*}{$96-01$} & group 1 & 4 & 0.209 & 0.418 & 0.791 & 4 & 0.161 & 0.323 & 0.839 \\
\hline & group 2 & 17 & 0.907 & 0.186 & $0,093 *$ & 15 & 0.851 & 0.299 & 0.149 \\
\hline \multirow{2}{*}{$02-06$} & group 1 & 12 & 0.174 & 0.348 & 0.826 & 6 & $0,056^{*}$ & 0.112 & 0.944 \\
\hline & group 2 & 19 & 0.973 & $0,054^{*}$ & $0,027^{*}$ & 16 & 0.971 & $0,058^{*}$ & $0,029^{*}$ \\
\hline \multirow{2}{*}{$07-11$} & group 1 & 26 & 0.389 & 0.778 & 0.611 & 14 & 0.384 & 0.768 & 0.616 \\
\hline & group 2 & 25 & 0.546 & 0.908 & 0.454 & 17 & 0.635 & 0.731 & 0.365 \\
\hline & & \multicolumn{4}{|c|}{ Political Stability \& Absence of Violence (PV) } & \multicolumn{4}{|c|}{ Rule of Law (RL) } \\
\hline \multirow{2}{*}{$96-01$} & group 1 & 7 & $0,056^{*}$ & 0.111 & 0.944 & 8 & 0.227 & 0.455 & 0.773 \\
\hline & group 2 & 10 & 0.348 & 0.696 & 0.652 & 16 & 0.599 & 0.803 & 0.401 \\
\hline \multirow{2}{*}{$02-06$} & group 1 & 13 & 0.280 & 0.559 & 0.720 & 11 & 0.125 & 0.250 & 0.875 \\
\hline & group 2 & 15 & 0.657 & 0.686 & 0.343 & 17 & 0.689 & 0.621 & 0.311 \\
\hline \multirow{2}{*}{$07-11$} & group 1 & 14 & 0.679 & 0.642 & 0.321 & 17 & 0.361 & 0.722 & 0.639 \\
\hline & group 2 & 20 & 0.145 & 0.289 & 0.856 & 15 & 0.479 & 0.957 & 0.521 \\
\hline & & \multicolumn{4}{|c|}{ Government Effectiveness (GE) } & \multicolumn{4}{|c|}{ Control of Corruption (CC) } \\
\hline \multirow{2}{*}{ 96-01 } & group 1 & 4 & 0.587 & 0.826 & 0.413 & 8 & $0,060^{*}$ & 0.121 & 0.940 \\
\hline & group 2 & 12 & 0.872 & 0.256 & 0.128 & 11 & 0.939 & 0.121 & $0,061^{*}$ \\
\hline \multirow{2}{*}{$02-06$} & group 1 & 11 & 0.387 & 0.775 & 0.613 & 14 & 0.182 & 0.364 & 0.818 \\
\hline & group 2 & 17 & 0.935 & 0.130 & $0,065^{*}$ & 15 & 0.769 & 0.462 & 0.231 \\
\hline \multirow{2}{*}{$07-11$} & group 1 & 16 & 0.370 & 0.739 & 0.630 & 13 & 0.134 & 0.267 & 0.866 \\
\hline & group 2 & 19 & 0.647 & 0.705 & 0.353 & 16 & 0.342 & 0.684 & 0.658 \\
\hline
\end{tabular}

Note: *P-Value significant at 10 percent.

Table 3 shows the results of testing analysis of investment in PPP projects across periods. For group B, countries with changes between 1996-2001 and 2007-2011, according to their estimation of regulatory quality, and control of corruption, tend to have a higher level of investment in PPP projects. Moreover, countries in group A show a significant relationship between decline of regulatory quality and rule of law estimations and lower investment.

\subsection{Summary of results}

Overall, the analysis per period shows that in group 2 certain aspects of governance have an impact on the level of investment in transportation PPP projects in the first two periods. In particular, countries with higher voice and accountability values tend to have more investment in PPPs. Moreover, government effectiveness, regulatory quality, and control of corruption have significant influence on the investment in some periods, but the results for the indicators are not consistent over the three periods. The last period is especially challenging since the analysis does not detect a significant relation between any of the governance indicators and the investment in PPPs. Further analysis is required to clarify this point. 
Table 3: $\quad$ PPP investment across periods.

\begin{tabular}{|c|c|c|c|c|c|}
\hline \multicolumn{2}{|c|}{ WGI Indicators } & \multicolumn{4}{|c|}{ Investment PPPs } \\
\hline Period & Group & Obs. & $\mathrm{H}_{\mathrm{a}}: \mu<\mathrm{H}_{\mathrm{o}}$ & Ha: $\mu !=\mathrm{H}_{0}$ & Ha: $\mu>\mathrm{H}_{\mathrm{o}}$ \\
\hline \multicolumn{6}{|c|}{ Voice and Accountability (VA) } \\
\hline \multirow{2}{*}{$96-01 / 07-11$} & group A & 18 & 0,562 & 0,877 & 0,438 \\
\hline & group B & 20 & 0,806 & 0,389 & 0,195 \\
\hline \multicolumn{6}{|c|}{ Political Stability and Absence of Violence (PV) } \\
\hline \multirow{2}{*}{$96-01 / 07-11$} & group A & 12 & 0,792 & 0,417 & 0,209 \\
\hline & group B & 21 & 0,652 & 0,696 & 0,348 \\
\hline \multicolumn{6}{|c|}{ Government Effectiveness (GE) } \\
\hline \multirow{2}{*}{$96-01 / 07-11$} & group A & 17 & 0,182 & 0,365 & 0,818 \\
\hline & group B & 13 & 0,574 & 0,852 & 0,426 \\
\hline \multicolumn{6}{|c|}{ Regulatory Quality (RQ) } \\
\hline \multirow{2}{*}{$96-01 / 07-11$} & group A & 12 & $0,059^{*}$ & 0,118 & 0,941 \\
\hline & group B & 12 & 0,923 & 0,153 & $0,077^{*}$ \\
\hline \multicolumn{6}{|l|}{ Rule of Law (RL) } \\
\hline \multirow{2}{*}{$96-01 / 07-11$} & group $\mathrm{A}$ & 14 & $0,087^{*}$ & 0,174 & 0,913 \\
\hline & group B & 10 & 0,311 & 0,621 & 0,689 \\
\hline \multicolumn{6}{|c|}{ Control of Corruption (CC) } \\
\hline \multirow{2}{*}{$96-01 / 07-11$} & group A & 16 & 0,159 & 0,318 & 0,841 \\
\hline & group B & 18 & 0,955 & $0,089^{*}$ & $0,045^{*}$ \\
\hline
\end{tabular}

Note: *P-value significant at 10 percent, GA: governance decline, GB: governance improvement.

The analysis across periods shows a significant relationship between improvement in governance over time and a tendency to a higher level of investment; especially, group B results reflect an improvement on regulatory quality, and control of corruption indicators are related with a higher level of investment on PPP projects. Variables of Voice and accountability and government effectiveness do not show significant evidence of influence on the investment.

For the two hypotheses, variables of rule of law, and political stability and absence of violence seem to have no impact on higher level of investment in transportation PPP projects.

\section{Conclusions}

This study takes a quantitative approach to the examination of the impact of a country's institutional environment on the level of participation of the private sector in transport infrastructure investment. To characterise the quality of institutions we use six dimensions that represent key aspects of the institutional environment. To characterise the level of investment in PPP project we use data taken from PPI database. In our analysis we cover 80 middle-and-low countries for the period 1996-2011.

The analysis shows that countries with better institutional environment tend to have a higher level of investment in PPP projects in two of the three periods considered. This influence is significant for the indicator voice and accountability. This means that countries with higher participation of their 
citizens in the selection of the government, freedom of expression and association have a higher level of investment in PPPs. Indicators of government effectiveness, regulatory quality, and control of corruption reflect some influence on the investment, but to a lesser degree. However, contrary to other studies, the indicator rule of law does not show a significant relationship with higher level of investment.

Moreover, the results show that countries that have improved over time in regulatory quality and control of corruption tend to have a higher level of investment though PPP projects.

These results make a strong case for the developing countries to keep improve the quality of their institutional environment in order to increase the level of investment in PPP projects.

\section{References}

[1] Economist Intelligence Unit, Evaluating the environment for publicprivate partnerships in Latin America and the Caribbean: The 2010 Infrascope, Report commissioned by the Multilateral Investment Fund (a member of the Inter-American Development Bank Group) and the Spanish Ministry of Economy, 2010.

[2] Private Participation in Infrastructure Project Database, ppi.worldbank.org

[3] Kenny, C., Infrastructure governance and corruption: where next? Vol. 4331. World Bank Publications, 2007.

[4] Carpintero S., López Corral A. \& Sánchez A., Las concesiones de infraestructuras de transporte en los países del centro y este de Europa: influencia del entorno institucional. Revista de obras Publicas, No. 3.4992, pp. 7-12, 2008.

[5] Carpintero S., Toll Roads in central and eastern Europe: promises and performance. Transport Reviews, No. 3, pp. 337-359, 2010.

[6] Kierzenkowski R., The challenge of rapidly improving transport infrastructure in Poland, OECD, No. 640, 2008.

[7] OECD, Principles for private sector participation in Infrastructure, Paris, OECD, 2007.

[8] Worldwide Governance Indicators (WGI), www.govindicators.org

[9] Pargal S., Regulation and private sector investment in infrastructure: Evidence from Latin America. World Bank policy research working paper, (3037), 2003.

[10] Jensen, O. \& Blanc-Brude F., The Institutional Determinants of Private Sector Participation in the Water and Sanitation Sector in Developing Countries, 4th Conference on Applied Infrastructure Research, Berlin, Russia, 2005.

[11] Jensen, O. \& Blanc-Brude F., The handshake: why do governments and firms sign private sector participation deals? Evidence from the water and sanitation sector in developing countries. World Bank Policy Research Working Paper 3937, 2006. 
[12] Al-hmoud, R. B. \& Edwards, J., A means to an end: studying the existing environment for private sector participation in the water and sanitation sector. International Journal of Water Resources Development, 20(4), 507-522, 2004.

[13] Percoco, M., Quality of institutions and private participation in transport infrastructure investment: Evidence from developing countries. Transportation Research Part A: Policy and Practice, 70, 50-58, 2014.

[14] Chan, A. P., Lam, P. T., Chan, D. W., Cheung, E., \& Ke, Y., Critical success factors for PPPs in infrastructure developments: Chinese perspective. Journal of Construction Engineering and Management, 136(5), 484-494, 2010.

[15] Zhang, X., Critical success factors for public-private partnerships in infrastructure development. Journal of Construction Engineering and Management, 131(1), 3-14, 2005.

[16] Hammami, M., Ruhashyankiko, J.F. \& Yehoue, E.B., Determinants of Public Private Partnerships in Infrastructure, Working Paper N. 06/99, International Monetary Fund, 2006.

[17] Sharma, C, Determinants of PPP in infrastructure in developing economies. Transforming Government: People, Process and Policy, 6(2), 149-166, 2012.

[18] World Development indicators, data.worldbank.org

[19] Kaufmann D., Kraay A. \& Zoido-Lobaton P., Governance Matter, World Bank Policy Research Working Paper No. 2196, Washington, D.C., 1999.

[20] Kaufmann, D.; Kraay, A. \& Mastruzzi, M., Governance Matters IV: Governance Indicators for 1996-2004. World Bank Policy Research Working Paper No. 3630. Washington, D.C., 2005.

[21] Kraay, A., Mastruzzi, M., \& Kaufmann, D., The worldwide governance indicators project: answering the critics. World Bank Publications, 2007.

[22] Kaufmann D., Kraay A., \& Mastruzzi M., Growth and Governance: A reply/Rejoinder. Journal of Politics. 69(2), 555-562, 2007.

[23] Kaufmann, D., Kraay, A., \& Mastruzzi, M., Response to: "The Worldwide Governance Indicators: Six, One, or None". Viewed online: http://info. worldbank.org/governance/wgi/resources.htm 2010.

[24] Kaufmann, D., Kraay, A., \& Mastruzzi, M., Response to 'What do the Worldwide Governance Indicators Measure\&quest'. European Journal of Development Research, 22(1), 55-58, 2010.

[25] Kaufmann, D., Kraay, A., \& Mastruzzi, M., The worldwide governance indicators: methodology and analytical issues. Hague Journal on the Rule of Law, 3(02), 220-246, 2011. 